\title{
Editorial
}

The summer issue of Legal Information Management (LIM) has a simple format on this occasion; it features two main sections - a theme and a current issues section.

\section{SOURCES AND METHODS IN CRIMINOLOGY AND CRIMINAL JUSTICE}

The theme is entitled Sources and Methods in Criminology and Criminal Justice and is based on the presentations delivered at a socio-legal training day that took place in November 2015 at the Institute of Advanced Legal Studies in London (IALS). The event was co-organised by the IALS, the Socio-Legal Studies Association (SLSA), British Library and the British Society of Criminology. I am greatly indebted to David Gee who helped to arrange the training day and then subsequently provided a considerable amount of time to help encourage presenters to write for this journal so that we could capture something of the event for publication here. This collaboration with LIM is the third of its kind in what has become a successful series of themes. The previous two collections of papers delivered at a National Training Day were on Legal Biography, which was published in LIM in the spring issue 2014 (I4(I)), and Law, Gender and Sexuality: Sources and Methods in Socio-Legal Research which can be found in spring 2015 (I5(I)). I hope that we can continue to build on these opportunities in the future as the events, and their subsequently published outputs, represent a close link between the research activities of academic colleagues and the sources and methods employed, which are by their very nature of great interest to us as librarians and information professionals. Once again, here we find a combination of articles written by leading academics in the criminology field but also by librarians, those with an interest in archives and records management. The subject matter of criminology takes us away from our usual legal context to a related field and there is much with which to be fascinated in this collection of essays. I will leave it to David Gee in the next few pages to describe the content in his capacity as Guest Editor on this occasion.

\section{CURRENT ISSUES}

There are three article listed in the Current Issues section in this journal. Firstly, we have a contribution from Ginevra Peruginelli in which she discusses the issues relating to access to law and justice with the main element of title being, "Law Belongs to the People". Daniel Bates provides us with the second of his two articles (part one was published in the previous issue (16 (I))) entitled, Tunes, Tubes and Clouds: Getting Your InHouse Talent out of the House and Online. Part 2: Distribution. Finally, Hester Swift highlights the success of the BIALL-IALS Foreign and International Law Courses, an invaluable and instructive training session delivered by legal information professionals.

\section{CURRENT AWARENESS}

As ever, special gratitude goes to Katherine Read and Laura Griffiths of the Institute of Advanced Legal Studies for the current awareness section that, as always, was delivered in excellent time ahead of publication.

\section{ACKNOWLEDGEMENTS}

As the editor of LIM I am very grateful to all the contributors and, once again, to David Gee who has contributed greatly to the work of this issue. Moreover, thanks also go to our colleagues at Cambridge University Press, especially Craig Baxter and Hannah Patrick, and to all the members of the LIM Editorial Board including the Chair of that committee, Dunstan Speight and the team of proof-readers. 